\title{
A new monorchiid cercaria (Digenea) parasitising the purple clam Amiantis purpurata (Bivalvia: Veneridae) in the Southwest Atlantic Ocean, with notes on its gonadal effect
}

\author{
Florencia Cremonte $^{1,2}$, Marina Andrea Kroeck ${ }^{3}$ and Sergio Roberto Martorelli ${ }^{1}$ \\ ${ }^{1}$ Centro de Estudios Parasitológicos y de Vectores (CONICET-UNLP), Calle $2 \mathrm{n}^{\circ}$ 584, (1900) La Plata, Argentina; \\ ${ }^{2}$ Centro Nacional Patagónico (CONICET), Boulevard Brown s/n, (9120) Puerto Madryn, Argentina; \\ ${ }^{3}$ Instituto de Biología Marina y Pesquera “Almirante Storni” (UNC-GPRN), C.C. 104, (8520) San Antonio Oeste, Argentina
}

Key words: Digenea, Monorchiidae, cercaria, metacercaria, Bivalvia, Veneridae, Argentine Sea

\begin{abstract}
An unnamed microcercous cercaria (Digenea: Monorchiidae), a parasite of Amiantis purpurata (Lamarck, 1818) (Bivalvia: Veneridae) and its corresponding metacercaria from the province of Buenos Aires and the Patagonian coast of the Southwest Atlantic Ocean, are described. The cercaria described in this paper differs from the three other monorchiid microcercous cercariae, i.e., Lasiotocus minutus (Manter, 1931), Lasiotocus elongatus (Manter, 1931), and Cercaria caribbea XXXVI Cable, 1956, mainly because of the extension of the excretory vesicle and the location of the ventral sucker. Cercariae artificially extracted from sporocysts encyst in a dish and form metacercariae enveloped by a gelatinous sac with two prolongations, which are used to adhere to the substratum. The monorchiid described in this paper has a life cycle similar to those of L. minutus and L. elongatus, although the adult stage of the present species is still unknown. Their larvae are similar in morphology and have venerid clams as their first hosts. The presence of a monorchiid larva is reported for the first time in the Southern Hemisphere. Its monthly prevalence rates, ranging from 0 to 25\% (mean: 8.3\%), are given from the Patagonian coast. The infection seems to cause castration as it was observed that during March through to May, when most gametes were produced in uninfected individuals, $81 \%$ of the infected individuals did not produce gametes.
\end{abstract}

Cercariae of the family Monorchiidae Odhner, 1911 normally develop in sporocysts in marine bivalves. Members of the genus Asymphylodora Looss, 1890 (subfamily Asymphylodorinae Szidat, 1943), on the other hand, have rediae that develop in gastropods (Lauckner 1983). According to Cable (1956), the status of Asymphylodora as a genus of the Monorchiidae is seriously questionable. To date, sixteen monorchiid cercariae that develop in sporocysts from bivalves have been described, all of them from the Northern Hemisphere, but the complete life cycles are known for only seven species (Martin 1940, Young 1953, De Martini and Pratt 1964, Maillard 1975, Stunkard 1981a, b, Bartoli et al. 2000). The metacercariae occur in seawater or in the same species of bivalve within the sporocyst or in other bivalves, and the adults live in the intestine of teleost fishes. The presence of Monorchiidae in the Southwest Atlantic Ocean is only known for adult forms in teleost fishes from Brazil (Amato 1982) and from Tierra del Fuego, southern Argentina (Szidat 1950).

The aim of this paper is to describe the morphology of a new cercaria found in Amiantis purpurata (Lamarck, 1818) (Bivalvia: Veneridae) and that of its corresponding metacercaria, from the province of Buenos Aires and the Patagonian coast, Southwest Atlantic Ocean. Moreover, we provide data on their monthly prevalence rates and notes on the effects on the gonadal development of parasitised clams.

\section{MATERIALS AND METHODS}

Amiantis purpurata is found from Rio de Janeiro, Brazil to San Matías Gulf, Argentina. In the southern limit of its distribution, the purple clam is commonly found in sandy substrates, from the intertidal zone until a depth of $15 \mathrm{~m}$ (Morsan E.M., IBMyP “Alte. Storni”, San Antonio Oeste, Argentina; pers. comm.). In this zone it is exploited for consumption on the internal market but it has also started to be exported to Europe (Lasta et al. 1998). The clam samples were taken on the coast of the province of Buenos Aires: Mar Azul $\left(37^{\circ} 15^{\prime} \mathrm{S}, 56^{\circ} 57^{\prime} \mathrm{W}\right)$ and Mar Chiquita (37 $46^{\prime} \mathrm{S}$, $\left.57^{\circ} 27^{\prime} \mathrm{W}\right)$, and in Northern Patagonia: Villarino beach, San Matías Gulf ( $\left.40^{\circ} 50^{\prime} \mathrm{S}, 64^{\circ} 45^{\prime} \mathrm{W}\right)$ (Fig. 1).

For morphological studies, well-preserved clams that were found dead on beaches after storms, were collected on the coast of the province of Buenos Aires (Mar Azul, December $1996, \mathrm{n}=17$, range of maximum height: $26-54 \mathrm{~mm}$, mean: 40 $\mathrm{mm}$; Mar Chiquita, April 1997, $\mathrm{n}=5$, range of maximum height: $37-49 \mathrm{~mm}$, mean: $41 \mathrm{~mm}$ ). The clams were fixed in $4 \%$ formaldehyde, stored in $70 \%$ ethanol and dissected under a stereomicroscope. Larvae were stained with Semichon's aceto-carmine, cleared in creosote and mounted in Canada balsam.

During a reproductive study of Amiantis purpurata, performed at Villarino beach on the Northern Patagonian coast, 
the same monorchiid parasite was found as in the province of Buenos Aires. From December 1993 to December 1994 (except in October 1994), monthly samples of 20 individuals (range of maximum height: $25-56 \mathrm{~mm}$, mean: $42 \mathrm{~mm}$ ) were taken; they represented a 14-15 year-old age-class (Morsan E.M., pers. comm.). Amiantis purpurata has separate sexes; from the total reproductive sampling $52 \%$ were males and $48 \%$ were females. The soft tissues of all clams were fixed in Bouin's fixative, stored in $70 \%$ ethanol, and later dehydrated, embedded and sectioned $(5-7 \mu \mathrm{m})$ following standard histological procedures. Sections were stained with eosin and Harris' haematoxylin. From these histological samples, data of monthly prevalence and parasitic effects on the gonadal development were studied.

The probability of occurrence according to binomial and Poisson distributions was calculated using $\mathrm{P}(\mathrm{p})$ (= total number of parasitised clams / number of total clams) in order to test the likelihood of finding a certain number of parasitised clams in each monthly sample $(\mathrm{x}=0,1,2,3,4$ or 5$)$.

With the objective of studying living larvae, clams from Villarino beach were collected on three occasions. They were placed in individual flasks, and the seawater was examined for cercarial emergence twice every 24 hours; later the clams were dissected. On the two first occasions, August 1999 (n = $100)$ and March $2000(\mathrm{n}=150)$ the results were negative. The third occasion was in June 2000 when 440 clams were studied; emergence was not observed but one parasitised clam was found. Larvae were studied living, both stained, with Neutral red and Nile blue, and unstained. For measurements, larvae were fixed in hot $4 \%$ seawater formaldehyde, measured, pre-served in $70 \%$ ethanol, stained with Semichon's acetocarmine, cleared in creosote, and mounted in Canada balsam. The measurements are based on 10 specimens of each larval stage and the drawings were made with the aid of a camera lucida. The means with the range in parentheses are given in micrometres.

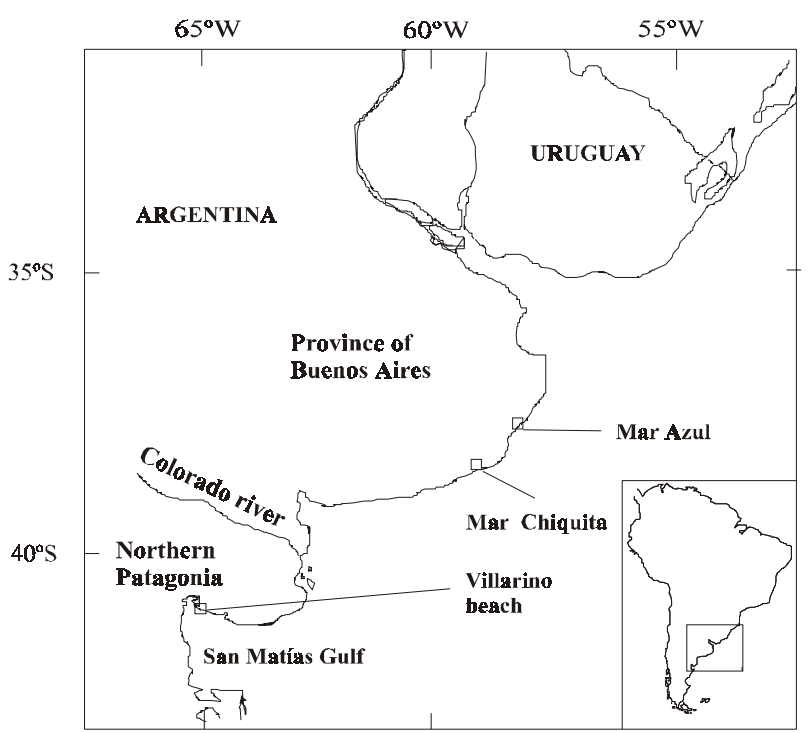

Fig. 1. Collecting localities of the purple clam Amiantis purpurata.

\section{RESULTS}

According to Cable (1956) and Schell (1985) a monorchiid cercaria can be identified by the following characteristics: distome, pharyngeate larvae, tegument spinose, eyespots present or absent, stylet lacking, excretory vesicle not thin-walled, and a long and slender tail, with lateral lappets, reduced, brevifurcate or per-haps even lacking.

\section{Monorchiid cercaria sp.}

Figs. 2-4

Sporocyst (Fig. 2): Colourless, inmotile, and thickwalled, 873 (520-1200) long by a maximum of 152 (120-170) wide. Nine to 27 microcercous cercariae (mean: 14) at different developmental stages in each sporocyst.

Cercaria (Fig. 3) (not released, larger specimens measured): Body elongate, 362 (283-450) long by 72 (59-78) wide at acetabulum level. Tegumental spines in transverse rows, prominent as far as ventral sucker and inconspicuous posteriorly. Two pairs of penetration glands located dorsally to oral sucker, opening in four pores at anterior end. Oral sucker 49 (43-52) long by 49 (40-58) wide, opening subterminally. Ventral sucker 50 (42-53) long by 51 (41-62) wide. Forebody length 145 (100-168). Sucker length ratio $1: 0.98$ (1:0.97 to 1 : 1.02). Prepharynx 20 (8-29) long. Pharynx 26 (20$30)$ long by 25 (22-28) wide. Oesophagus 14 (10-20) long. Caeca subterminal. Prominent cystogenous cells scattered throughout length of body. Excretory bladder I-shaped with thick wall and narrow lumen, overlapping ventral sucker. Flame cell formula: $2[(2+2)+(2+2)]$ $=16$. Tail, a tiny knob, 14 (11-16) in diameter.

Metacercaria (Fig. 4): Cyst 123 (111-156) in diameter. Wall of cyst 6 (4-9) in thickness. Cyst surrounded by a colourless, gelatinous and sticky sac, with two prolon-gations - a shorter one, 88 (73-98) in length, and a longer one, 279 (225-342) in length. Adhesive prolonga-tions maintained the attachment of metacercariae along their entire length to the bottom of the Petri dish. Penetration glands still distinguishable dorsally to oral sucker.

$\mathrm{H}$ o s t: Amiantis purpurata (Lamarck, 1818) (Bivalvia: Veneridae).

S i t e of infection: Mainly the gonad and the digestive gland but also the mantle, the branchiae, the foot and around the intestine in cases of heavy infection.

L o cality and prevalen ce: Mar Azul (94.1\%), Mar Chiquita (100\%) and San Matías Gulf (8.8\%).

Deposition of specimens: Helminthological Collection of Museo de La Plata (CHMLP), Nos. 4807, 4808, 4809 and 4810, Museo de La Plata, La Plata, Argentina.

Taxonomic remarks: According to the morphology of the monorchiid cercariae, four groups can be distinguished (Table 1). The first group (1) is composed of 

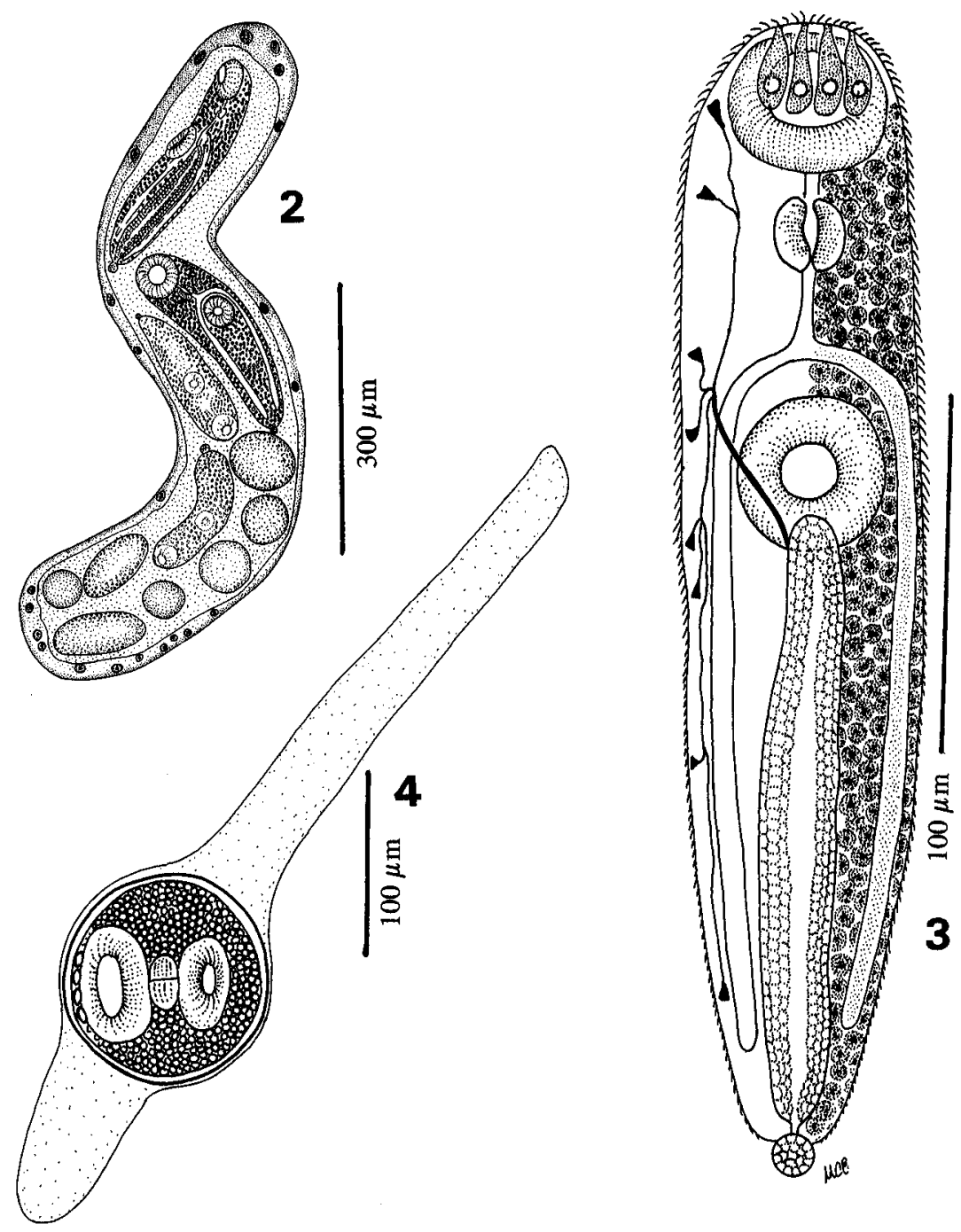

Figs. 2-4. Developmental stages of a monorchiid from the purple clam Amiantis purpurata. Fig. 2. Sporocyst. Fig. 3. Cercaria, dorsal view. Fig. 4. Encysted metacercaria, ventral view.

cercariae possessing a well-developed tail and usually ocelli, the second group (2) is made up of cercariae with shorter or collar-like tails; the third group (3) consists of cercariae with a short furcae without a tail stem; and those of the forth group (4) have a tiny knob tail and are without ocelli. The cercaria described in the present paper belongs to the fourth group together with Cercaria caribbea XXXVI Cable, 1956, Lasiotocus minutus (Manter, 1931) and Lasiotocus elongatus (Manter, 1931) (Cable 1956, Stunkard 1981a, b). It can be distinguished from L. minutus because the latter has a sac-shaped excretory vesicle and its ventral sucker is smaller than the oral sucker (sucker ratio: $1: 0.75$ ) (Stunkard and Uzmann 1959, Stunkard 1981a). The cercaria described in the present paper can be distinguished from C. caribbea XXXVI and Lasiotocus elongatus because these two have a shorter excretory vesicle, and their ventral sucker is located in the middle of the body (Cable 1956, Stunkard and Uzmann 1959, Holliman 1961, Stunkard 1981b). The metacercaria described in the present paper most closely resembles $L$. minutus and L. elongatus, but it can be distinguished from these two as follows: $L$. minutus has a smaller cyst (70-80 $\mu \mathrm{m}$ in diameter) that mainly floats (Stunkard 1981a; unfortunately in this case the cyst wall and the prolongations of the sac were not measured); and $L$. elongatus has a smaller cyst (70-75 $\mu \mathrm{m}$ in diameter), with a thinner wall $(3 \mu \mathrm{m})$, and its sac does not have prolongations (Stunkard 1981b).

In conjunction with the previous description and its comparison with group 4 larvae, it is suggested that the cercaria and metacercaria reported in the present paper are new. The larvae described in the present paper may correspond with some of the adults described by Szidat 
Table 1. Records of monorchiid cercariae, indicating their hosts and localities. First and second hosts are bivalves. G - morphological group (see text for explanations).

\begin{tabular}{|c|c|c|c|c|c|c|}
\hline Monorchiid cercaria & G & First host & Second host & Definitive host & Locality & Reference \\
\hline Cercaria myocerca Villot, 1878 & 1 & Scrobicularia tenuis & unknown & unknown & Northeast Atlantic Ocean & Martin 1938 \\
\hline $\begin{array}{l}\text { Monorcheides cumingiae (Martin, 1938) Martin, } \\
1940\end{array}$ & 1 & llinoides & $\begin{array}{l}\text { Cumingia tellinoides } \\
\text { Tellina tenera }\end{array}$ & Pseudopleuronectes americanus & Northwest Atlantic Ocean & 4 \\
\hline Postmonorchis donacis Young, 1953 & 1 & Donax & Donax gouldii & Embioticidae & Northeast Pacific Ocean & g 1953 \\
\hline Cercaria caribbea & 1 & Maco & unknown & un & Rico & $\mathrm{C}$ \\
\hline Cerc & 1 & Do & & & & 1961 \\
\hline Cerc & 1 & Tell & Tellina mar & & & $\mathrm{Ca}$ \\
\hline Cerc & 1 & Codakia & & & & 53 \\
\hline Cerc & 1 & Venus fas & $\begin{array}{l}\text { unknown } \\
\text { Abra ovata }\end{array}$ & un & Sea, France & Bartoli 1966 \\
\hline Paratimonia gobii Prévot et Bartoli, 1967 & 1 & Abra ovata & $\begin{array}{l}\text { Cerastoderma glaucum } \\
\text { Parvicardium exiguum } \\
\text { Mytilus galloprovincialis }\end{array}$ & Pomatoschistus microps & Mediterranean Sea, France & $\begin{array}{l}\text { Maillard } 1975 \\
\text { Bartoli } 1984\end{array}$ \\
\hline & & Cerastoderma edule & & & Northeast Atlantic Ocean & Sannia et al. 1978 \\
\hline Monorchis parvus Looss, 1902 & 2 & $\begin{array}{l}\text { Cerastoderma } \\
\text { glaucum }\end{array}$ & Cerastoderma edule & Diplodus & Mediterranean Sea, France & Bartoli et al. 2000 \\
\hline Cercaria choanura $\mathrm{I}$ & 2 & Donax variabilis & $\begin{array}{l}\text { Donax variabilis } \\
\text { Donax tumida }\end{array}$ & unk & Gulf of Mexico, USA & Hopkins 1958 \\
\hline Telolecithus pugetensis Lloyd et Guberlet, 1932 & 3 & Transennella tantilla & $\begin{array}{r}\text { Tellina salme } \\
\text { Macoma nas } \\
\text { oth }\end{array}$ & $\begin{array}{l}\text { Cymatogaster aggregata } \\
\text { Embiotoca lateralis } \\
\text { Phanerodon furcatus }\end{array}$ & Northeast Pacific Ocean & De Martini and Pratt 1964 \\
\hline Cercaria caribbea & 4 & $\begin{array}{l}\text { Gemma } 1 \\
\text { Chione c }\end{array}$ & unkr & then & Puerto Rico & $\begin{array}{l}\text { Cable } 1956, \\
\text { Holliman } 19\end{array}$ \\
\hline Lasi & 4 & Gem & & Meni & $\mathrm{N}$ & d 1981a \\
\hline Lasic & 4 & Gem & & Menid & & $1981 b$ \\
\hline Monorchiid cercaria sp. & 4 & Amiantis purpurata & none & unknown & Southwest Atlantic Ocean & Present study \\
\hline
\end{tabular}




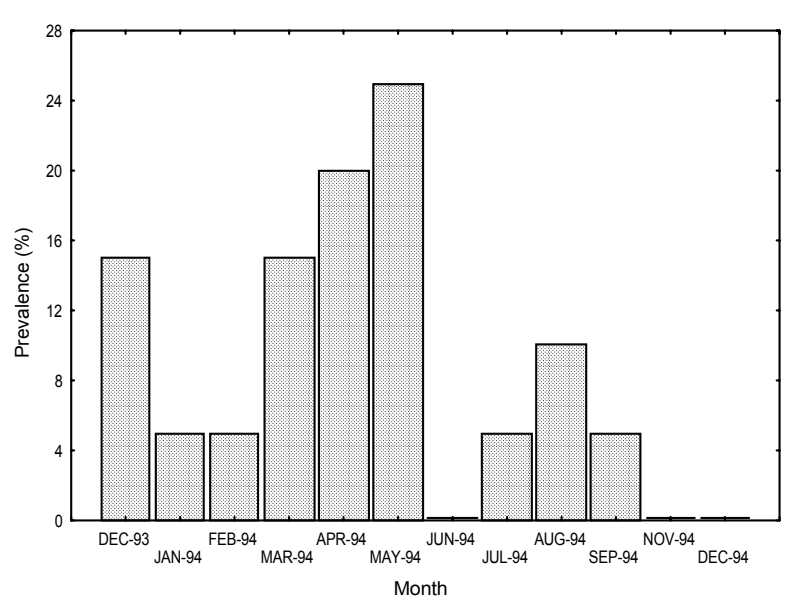

Fig. 5. Monthly prevalence of the monorchiid cercaria parasitic in the purple clam Amiantis purpurata in Villarino beach, San Matías Gulf (each month, $\mathrm{n}=20$ ).

(1950) and Amato (1982) in the Southwest Atlantic Ocean. Further studies in order to obtain the adult form of this parasite will be required to give a specific name to the cercaria and metacercaria described in the present paper.

\section{Monthly prevalence and gonadal effects}

Monthly prevalence from San Matías Gulf is given in Fig. 5. The highest prevalence occurred in autumn with the maximum in May (5 infected / 20 examined clams; $25 \%)$, followed by April (4/20; 20\%) and March (15\%). Non-parasitised clams were found in June, November and December 1994. Considering the total number of clams examined and the overall parasite prevalence, the probability that the high prevalence rates in May and April were purely incidental is below 5\% and 10\%, respectively (Table 2). It is therefore concluded that these data suggest seasonality of infection with an autumn maximum.

Table 2. Binomial and Poisson probabilities, $P(p)=0.09$, of a certain number $(x)$ of parasitised clams in a monthly sample.

\begin{tabular}{|c|c|c|}
\hline$\times$ & $\mathrm{P}(\times)$ Binomial & $\mathrm{P}(\times)$ Poisson \\
\hline 0 & 0.1516 & 0.1740 \\
1 & 0.3000 & 0.3039 \\
2 & 0.2828 & 0.2659 \\
3 & 0.1672 & 0.1552 \\
4 & 0.0703 & 0.0679 \\
5 & 0.0222 & 0.0238 \\
\hline
\end{tabular}

Our studies on the reproduction of $A$. purpurata (unpublished data) revealed its intense gametogenic activity in winter months with total maturation at the beginning of the spring. The clam spawns from the end of spring until the end of the summer, and most spawn stages occur during February and March. At the beginning of autumn most individuals are in the proliferative stage. In contrast to this general pattern, of 21 infected clams 17 individuals $(81 \%)$ had no gametes in the gonads and the remaining 4 individuals ( 1 male, 3 females) that did produce gametes harboured just a few sporocysts with poorly developed cercariae. This suggests that the cercarial infection caused castration.

\section{DISCUSSION}

It is remarkable that the four cercariae belonging to group 4 (see Table 1) were found in venerid clams. Taking into account the high specificity that digeneans have to their first host together with the morphological similarities of the group 4 cercariae, it seems that they belong to related species. Also, the life cycles of these parasites have some similarities. In this sense, Cable (1956, 1963) observed that Cercaria caribbea XXXVI did not emerge, despite the great number of bivalves that he had isolated, and he never found metacercariae in the dissections. Holliman (1961), in his work with cercariae that he considered belonging to $C$. caribbea XXXVI, found that the cercariae are ejected by the excurrent siphon as encysted metacercariae enveloped by a gelatinous covering. Both Cable (1956) and Holliman (1961) reported an undetermined number of penetration glands in cercariae. Stunkard (1981a, b) reported that both cercariae of Lasiotocus minutus and L. elongatus encyst in the haemocoel of molluscs and are expelled as metacercariae; both matured in Menidia menidia (Pisces: Atherinidae). Stunkard and Uzmann (1959) reported the presence of penetration glands, but Stunkard (1981a) could not confirm this observation; he reasoned that since the cercaria does not invade a second intermediate host, there is no reason for penetration glands. Moreover, Stunkard (1981b) mentioned that in L. elongatus the cystogenous glands might simulate penetration glands. None of the previous authors could precisely determine the presence, or the number of pene-tration glands. This may be because they are difficult to distinguish from the cystogenous glands that are scattered through the body parenchyma, and that both glands stain with vital stains. In the cercaria described in the present paper, we observed the penetration glands in an unusual position, lying dorsally to the oral sucker, as confirmed in histological sections (not shown). Since cercariae encysted in a dish, such glands could be involved in the secretion of the gelatinous sac that enveloped the encysted metacercaria.

With regard to the site of infection of Monorchiidae, Telolecithus pugetensis Lloyd et Buberlet, 1932 and Monorcheides cumingiae (Martin, 1940) occur in the visceral mass, even around the gut, causing sterility and other disturbances (Martin 1940, De Martini and Pratt 1964). Holliman (1961) found the sporocysts in the gonad. Cercaria longicaudata Bartoli, 1966 invades the visceral mass, castrating the clam (Bartoli 1966). 
Monorchis parvus Looss, 1902 occurs in the haemocoel of the digestive gland, in the gonad, and in the foot, causing severe damage and massive mortality by impairing the burrowing ability of the clam (Sannia et al. 1978, Jonsson and André 1992). In the present case, the sporocysts mainly invaded the digestive gland and the gonad, but in heavy infections could also be found in the connective tissue of the mantle, around the gut, the branchiae and the foot.

Since $97 \%$ of the clams collected after storms on the beaches of the province of Buenos Aires were parasitised, and taking into account that this parasite probably causes castration, it is very probable that in natural beds, such as on the Patagonian coast, prevalence would be much lower. Thus this strongly suggests that the monorchiid cercaria reported in the present paper debilitates the clams by impairing their burrowing ability and hence, the clams are washed up on the beach after strong storms. The infection seems to cause castration because during March through to May, when most gametes were produced in uninfected individuals, $81 \%$ of the infected individuals were not producing gametes.
The presence of a monorchiid larva is reported for the first time in the Southern Hemisphere and there are also no previous records of members of the family in the latitudes ranging from $27^{\circ} \mathrm{S}$ to $41^{\circ} \mathrm{S}$ in the Southwest Atlantic Ocean.

Acknowledgements. The authors gratefully acknowledge one sample of bivalves from Juan Farina (Museo Municipal de Ciencias Naturales "Lorenzo Scaglia", Mar del Plata, Argentina), the drawings by María Cristina Estivariz (Centro de Estudios Parasitológicos y de Vectores, La Plata, Argentina), advice about the clam from Enrique M. Morsan (Instituto "Alte. Storni”, San Antonio Oeste, Argentina), statistical advice from Ramiro Sarandón (Facultad de Ciencias Naturales y Museo, La Plata, Argentina) and correcting of the English by Lucy Shirlaw (University of Manchester, United Kingdom). We also acknowledge the Instituto "Alte. Storni" for providing the laboratory for the histological studies. This study was funded by the Consejo Nacional de Investigaciones Científicas y Técnicas (CONICET). Our special thanks to Pierre Bartoli (Centre d'Océanologie de Marseille, France) for his valuable suggestions on the manuscript. The authors are indebted to three anonymous reviewers whose suggestions improved the manuscript.

\section{REFERENCES}

AMATO J.F.R. 1982: Digenetic trematodes of percoid fishes of Florianópolis, Southern Brazil - Monorchiidae, with the descriptions of two new species. Rev. Bras. Biol. 42: 701-719.

BARTOLI P. 1966: Contribution à l'étude des stades larvaires des Trématodes marins du littoral des Bouches-du-Rhône (France): Cercaria longicaudata n. sp. (Monorchiidae). Ann. Parasitol. Hum. Comp. 41: 301-306.

BARTOLI P. 1984: Distomatoses des lamellibranches marins sur le littoral méditerranéen francais. Haliotis 14: 98-107.

BARTOLI P., JOUSSON O., RUSSELL-PINTO F. 2000: The life cycle of Monorchis parvus (Digenea: Monorchiidae) demonstrated by developmental and molecular data. J. Parasitol. 86: 479-489.

CABLE R.M. 1956: Marine cercariae of Puerto Rico. Sci. Surv. Puerto Rico and Virgin Islands 16: 491-577.

CABLE R.M. 1963: Marine cercariae from Curaçao and Jamaica. Z. Parasitenkd. 23: 429-469.

DE MARTINI J.D., PRATT I. 1964: The life cycle of Telolecithus pugetensis Lloyd and Guberlet, 1932 (Trematoda: Monorchiidae). J. Parasitol. 50: 101-105.

HOLLIMAN R.B. 1961: Larval trematodes from Apalachee Bay area, Florida, with a checklist of known marine cercariae arranged in a key to their superfamilies. Tulane Stud. Zool. 9: 2-74.

HOPKINS S.H. 1958: Trematode parasites of Donax variabilis at Mustang Island, Texas. Publ. Inst. Mar. Sci. 5: 301-311.

JONSSON R., ANDRÉ C. 1992: Mass mortality of the bivalve Cerastoderma edule on the Swedish west coast caused by infection with the digenean trematode Cercaria cerastodermae I. Ophelia 36: 151-157.
LASTA M.L., CIOCCO N.F., BREMEC C.S., ROUX A.M. 1998: Moluscos bivalvos y gasterópodos. In: E.E. Boschi (Ed.), El Mar Argentino y sus Recursos Pesqueros Vol. 2. Instituto Nacional de Investigación y Desarrollo Pesquero, Mar del Plata, Argentina, pp. 115- 142.

LAUCKNER G. 1983. Diseases of Mollusca: Bivalvia. In: O. Kinne (Ed.), Diseases of Marine Animals. Vol. 2. Biologische Anstalt Helgoland, Hamburg, pp. 477-961.

MAILlARD C. 1975: Cycle évolutif de Paratimonia gobii Prévot et Bartoli, 1967 (Trematoda-Monorchiidae). Acta Tropica 32: 327-333.

MARTIN W.E. 1938: Studies on trematodes of Woods Hole: the life cycle of Lepocreadium setiferoides (Miller and Northup), Allocreadiidae, and the description of Cercaria cumingiae n. sp. Biol. Bull. (Woods Hole) 75: 463-474.

MARTIN W.E. 1940: Studies on trematodes of Woods Hole. III. The life cycle of Monorcheides cumingiae (Martin) with special reference to its effect on the invertebrate host. Biol. Bull. (Woods Hole) 79: 131-144.

SANNIA A., JAMES B.L., BOWERS E.A. 1978: The morphology of Cercaria cerastodermae I nom. nov. (Monorchiidae) (=Cercaria lepidapedon rachion (Cobbold, 1858) sensu Lebour, 1908) a rare digenean parasite of the cockle in Britain. J. Nat. Hist. 12: 487-500.

SCHELL S.C. 1985: Handbook of Trematodes of North America, North of Mexico. University Press Idaho, United States of America, $263 \mathrm{pp}$.

STUNKARD H.W. 1974: New intermediate hosts of the digenetic trematodes, Monorcheides cumingiae (Martin, 1938) and Neopechona pyriforme (Linton, 1900). J. Parasitol. 60: 859. 
STUNKARD H.W. 1981a: The life history, developmental stages, and taxonomic relations of the digenetic trematode Lasiotocus minutus (Manter, 1931) Thomas, 1959. Biol. Bull. (Woods Hole) 160: 146-154.

STUNKARD H.W. 1981b: The morphology, life history, and systematic relations of Lasiotocus elongatus (Manter, 1931) Thomas, 1959 (Trematoda: Digenea). Biol. Bull. (Woods Hole) 160: 155-160.

STUNKARD H.W., UZMANN H.W. 1959: The life-history of the digenetic trematode, Proctoeces maculatus (Looss,

Received 29 June 2000
1901) Odhner, 1911 [syn. P. subtenuis (Linton, 1907) Hanson, 1950], and a description of Cercaria adranocerca n. sp. Biol. Bull. (Woods Hole) 116: 184-193.

SZIDAT L. 1950: Los parásitos del róbalo ("Eleginops maclovinus" Cuv. \& Val.). Primer Congreso Nacional de Pesquerías Marítimas e Industrias Derivadas 2: 235-270.

YOUNG R.T. 1953: Postmonorchis donacis, a new species of monorchiid trematode from the Pacific coast, and its life history. J. Wash. Acad. Sci. 43: 88-93.

Accepted 16 January 2001 